\title{
Vårdmarknad med svårigheter \\ - om privata aktörer inom institutionsvården för barn och ungdomar
}

MARIE SALLN $\ddot{A}$

\begin{abstract}
Allt större andel av institutionsvården för barn och ungdomar drivs i privat regi. I artikeln behandlas hur den privata vården etablerats samt hur företrädare för institutionerna beskriver sin position och sitt agerande på den vårdmarknad som uppstått.
\end{abstract}

\section{Inledning}

Offentligt finansierade tjänster producerade i privat regi har blivit ett allt vanligare inslag inom många välfärdsområden. Tidigare har det funnits en mer eller mindre given arbetsfördelning i det svenska samhällets olika sfärer som inneburit att vissa fält har dominerats av offentliga aktörer, exempelvis vård, omsorg och socialtjänst. Under de senaste decennierna har det dock

Marie Sallnäs är docent i socialt arbete vid Stockholms universitet. Hon forskar om social barnavård och särskilt om socialtjänstens dygnsvård. skett avsevärda förskjutningar. Man kan uttrycka det som att sammansättningen av institutionella aktörer på olika fält omprövats, parallellt med att relationerna mellan aktörerna ändrats.

Institutionsvård för unga är ett område som förändrats påtagligt de senaste decennierna. I samband med Socialtjänstlagen 1982 infördes nya spelregler vilket lett till stora förändringar i vårdlandskapet och en anmärkningsvärd gränsomdragning mellan offentligt och privat. Fältet präglas idag alltmer av att privata vårdgivare som handelsbolag, aktiebolag och stiftelser bjuder ut vård/behandling till kommunernas social- 
tjänst. Andelen privat drift på detta fält framstår som mycket stor om man jämför med andra välfärdsområden, t.ex. skola, sjukvård och barnomsorg (Trydegård 2001). Uppgifterna är något osäkra men enligt Socialstyrelsen drevs närmare nio av tio institutioner för barn och unga, s.k. HVBhem, av någon typ av enskild huvudman (vinstdrivande eller icke-vinstdrivande/ideell) våren 2002 (Socialstyrelsen 2003). ${ }^{1}$ Ett liknande mönster av ökat privat utförande kan skönjas inte bara i Sverige, utan också i andra länder som Norge och Storbritannien (Benedictow 1996, Storø 1998, Gibbs \& Sinclair 1998).

Övergången till fler privata utförare har skett samtidigt med en ökning av både antalet barn som socialtjänsten över huvud taget placerar utanför hemmet och av andelen som placeras i institutionsvård (Sallnäs 2000, Socialstyrelsen 2002). Inom ett närliggande område som missbrukarvård ser utvecklingslinjerna annorlunda ut. Där har de privata aktörerna etablerat sig på ett totalt sett krympande fält. Andelen privata institutioner har ökat (från 21 procent 1990 till 41 procent 1999) men det har

1 Förkortningen HVB står för "hem för vård eller boende« som är socialtjänstlagens beteckning på yrkesmässigt bedriven dygnet-runt vård. Det saknas idag ett myndighetsbaserat nationellt register över existerande HVB-hem. Socialstyrelsens uppgifter bygger på underlag från KatalogData, ett privat företag. Siffrorna får betraktas som ungefärliga. En speciell kategori av institutioner utgör de särskilda ungdomshemmen, ofta kallade § 12-hem. De är till för de mest problembelastade ungdomarna och drivs av staten. § 12-hemmen behandlas inte i denna artikel. skett parallellt med en neddragning av antalet vårdplatser (SOU 2001:79, s. 119).

De senaste decenniernas utveckling har inneburit inte bara fler utan också dyrare institutionsplaceringar av unga. Vårdkostnaderna tar en allt större andel av individoch familjeomsorgens budget i kommunerna. Relativt andra typer av vårdinsatser är institutionsvård för unga en personalkrävande och dyr verksamhet. Ett vårddygn i institution är per barn nästan fem gånger dyrare än vård i familjehem (ett familjehem är en "vanlig familj" som mot arvode tar emot någon annans barn för att man skall bo tillsammans). Genomsnittskostnaden för institutionsvård var år 2000 drygt 2700 kr /dygn och för familjehem drygt 600 kr/ dygn. En kostnadsökning har skett inom bägge vårdformerna. Den inleddes i slutet av 1980-talet, ungefär samtidigt som de privata aktörerna dök upp inom institutionsvården i större omfattning (Socialstyrelsen 2002). Man kan dock inte på ett enkelt sätt knyta ökade kostnader till de privata institutionerna. Den knapphändiga tidigare kunskap som finns pekar på en mer komplicerad bild (Socialstyrelsen 1994, Lindqvist \& Sandblom 2003). Vid 1990-talets början innebar de privata aktörernas inträde att vård till lägre pris och med lägre kvalitet (mätt som personaltäthet) än den offentliga uppträdde på fältet. Parallellt växte mer personalintensiv privat institutionsvård fram, men dyrare än motsvarande offentlig vård (Lindkvist \& Sandblom 2003).

Det är kommunerna som har ansvar för att barn och ungdomar med sociala problem får vård och behandling, men utförandet av vården/behandlingen har sedan 1980-talets början alltså i allt större utsträckning läm- 
nats över till privat drivna institutioner. Det har uppstått en vårdmarknad som har sina egna spelregler och sina egna aktörer. Det finns emellertid lite kunskap om hur det privata fältet etablerats och gestaltar sig och om de aktörer som uppträder där. Syftet med denna studie är att fylla några av dessa kunskapsluckor genom att ta fasta på främst tre aspekter.

Den första handlar om att belysa vilken slags aktörer som finns på fältet samt deras etableringsprocess. Hur, när och varför har hemmen etablerat sig? Hur ser fördelningen ut mellan olika slags huvudmän och mellan små och stora? Har privatisering skett genom omvandling av offentliga verksamheter eller genom nyetablering? Den andra aspekten rör hur företrädare för de enskilda HVB-hemmen själva ser på sin roll som aktörer på en marknad och vilka strategier man använder för sitt agerande. Hur uppfattar man sin position på marknaden och relationerna till socialtjänsten och i vilken utsträckning bjuder man aktivt ut sina tjänster? Den tredje aspekten rör de privata hemmens avgiftsnivåer och vad som styr dessa. Vilka vårdavgifter tar hemmen ut av kommunerna och hur är avgiftsnivåerna relaterade till marknadssituation och andra förhållanden? Hur ser man från HVB-företrädares sida på pengars roll i verksamheten?

I artikeln skall presenteras resultat från en undersökning där telefonintervjuer gjorts med knappt hundra föreståndare för enskilda HVB som riktar sig till barn och ungdomar. Men först några reflektioner om det fält som de privata aktörerna trätt in på och den marknad som upprättats.

\section{Institutioner på en marknad - några utgångspunkter}

\section{Etablering av privata aktörer}

Enligt s.k. organisationsekologisk teori kan nyetablering på ett fält ske genom att enkelt sammansatta verksamheter utnyttjar svängningar och förändringar i samhället för att etablera sig utan allt för stora insatser (Hannan \& Freeman 1989). Denna typ av organisationer uppstår utan större svårigheter när inträdeshindren på ett fält är låga, men organisationerna är ofta sårbara och har kort livslängd. Institutioner för barn- och ungdomar, speciellt de mycket småskaliga verksamheter som blivit vanliga, kan ses som tämligen enkla organisationer möjliga att inrätta utan stora hinder eller investeringar. För att starta och driva ett privat HVB-hem krävs tillstånd från länsstyrelsen, lämpliga lokaler och ett antal personer som kan arbeta i verksamheten. Rapporter visar att kontrollerande myndigheter ställt få och oklara krav för att man ska få starta institutioner och att kontroll och uppföljning av innehållet i vården har fungerat dåligt (Kilsved \& Hartelius 1993, RRV 2002:6). Det har saknats externa "grindvakter" som rest etableringshinder och som bevakat pågående verksamheter. Också de inomprofessionella hindren har varit låga och här kan fältets bristande professionalisering ses som en viktig bidragande faktor. Sundin (1997) pekar på sambandet mellan yrkesområdens grad av professionalisering och hur benägna de verksamma är att starta privat drift. Inom svagt professionaliserade områden saknas ofta grupper som fungerar som hinder för aktörer som vill etablera sig 
utan rimlig erfarenhet och/eller kompetens. Institutionsvården för unga utmärks av låg utbildningsnivå om man jämför med exempelvis socialtjänstens personal. Särskilt gäller detta vid de privata HVB-hemmen (Sallnäs 2000). Privat drift och deprofessionalisering har med andra ord gått hand i hand på detta fält (se Dellgran \& Höjer 2003).

\section{Att vara aktörpå en vårdmarknad}

De HVB-hem som ingår i studien är alla "privata institutioner" $\mathrm{i}$ den meningen att de har någon typ av enskild huvudman (ej kommun, landsting eller stat). De kan vara vinstsyftande verksamheter ("for-profit") som enskild firma, handelsbolag/kommanditbolag och aktiebolag eller icke-vinstsyftande ("non-profit») i form av ideella och ekonomiska föreningar samt stiftelser (se Trydegård 2001). När begreppet privatisering av institutionsvården används i denna artikel avser det således den utveckling som inneburit att det som tidigare varit offentlig produktion i allt större utsträckning utförs av privata företag, men med bibehållen offentlig finansiering och reglering. ${ }^{2}$

Också begreppet marknad används. Det avser i sin grundläggande mening en mötesplats för köpare och säljare där över-

2 För läsbarhetens skull används begreppen »enskilda HVB-hem" respektive "privata HVBhem" som synonymer. Den formellt riktiga beteckningen på verksamheter som drivs av annan än kommun, lansting eller stat är dock termen "enskilda HVB-hem». enskommelser görs om köp eller försäljning av varor eller tjänster. Rent teoretiskt förutsätts att producenter fritt skall kunna etablera sig och konkurrera om kunderna. De skall producera varor/tjänster som skiljer sig åt så att ett varierat utbud uppstår som kunden fritt kan välja mellan (se Kotler \& Armstrong 2004). Vid missnöje med en vara eller tjänst skall man som kund kunna välja en annan.

HVB-hemmen kans sägas befinna sig på en marknad i den bemärkelsen att de säljer vård per dygn till socialtjänsten i landets knappt 300 kommuner. HVB-hemmen kan utforma sina tjänster efter vad man uppfattar att kommunerna efterfrågar, men de kan inte vända sig till någon annan köpare. Det är alltså en marknad med inskränkningar och med uppenbara avvikelser från marknadens grundläggande idé. Ibland används begreppet kvasimarknad för att beskriva situationer där man vill använda marknadsmekanismer men samtidigt begränsar dessa mekanismers räckvidd (se Montin 1996). Knapp et al. (2001) pekar på att »social care markets" inte fungerar enligt ekonomiska läroboksprinciper eftersom de i stor utsträckning formas av lokala myndigheter via deras upphandling och formulering av sina uppdrag. Allokering enligt grundläggande marknadsprinciper försvåras av problem med att mäta resultat av vården (som ofta tas för given som något gott) och av att måluppfyllelse ofta är en långdragen process. Vårdmarknader utmärks också av en asymmetrisk tillgång på information. Utförarna har ofta mer kunskap än köparna om vårdkvalitet och dess påverkan på brukarna. Dessutom kan vården i vissa fall tvingas på brukarna (klienterna). Dessa faktorer tagna 
var för sig är inte unika för vårdområdet, men i kombination innebär de påtagliga svårigheter för kunden/brukaren i samband med marknadifiering (se också Hugemark 2004).

Inom socialtjänstens institutionsvård för unga är flera av de faktorer Knapp et al. (a.a.) nämner högst påtagliga. Transaktionskostnaderna, dvs. det som krävs för att köpare och säljare skall kunna finna varandra och sluta avtal samt se till att de efterlevs, är höga. Ibland anses just tjänster inom vård och omsorg olämpliga för marknadifiering på grund av de höga transaktionskostnaderna, inte minst vad gäller den information som behöver samlas om tjänsterna. För att en marknad skall fungera krävs att köparen har tillgång till väsentlig information om alternativen på marknaden (Blomqvist \& Rothstein 2000, se också Montin 1996). Detta är knappast fallet när det gäller HVBvård för unga. Köparen står inför ett svåröverskådligt fält med en mängd olika alternativ till olika priser. Hemmen bedriver sällan systematisk utvärdering och uppföljning och när det gäller resultat av svensk institutionsvård saknas forskning som kan ge beslutsunderlag för den som står i begrepp att genomföra en placering (se Andreassen 2003, Egelund \& Heastbeck 2003). Det råder en informationsasymmetri som innebär att det är en svår eller hart när omöjlig uppgift att bedöma vad som skiljer den ena institutionen från den andra eller huruvida det arbete som görs är av god kvalitet. Det finns inte heller en gemensam uppfattning om vad som faktiskt konstituerar god kvalitet i dessa sammanhang. För de privata institutionernas del innebär detta ett spelutrymme när det gäller prissättningen samt stora möjligheter att utforma vård- och behandlingsarbetet efter eget huvud. Den "frihet" man här kan tala om anförs ofta som ett skäl för personer att starta eget företag, (se Österberg, 2003 om egna företagare i social- och hälsovård i Finland).

Köp/sälj situationen berör emellertid inte endast socialtjänsten och HVBhemmen. Det finns också brukare med i bilden. Begreppet brukare används ofta för att beteckna de personer som använder - och därmed också bör få påverka - en viss tjänst eller produkt (se Montin 1996). En kund däremot är någon som kan välja eller inte välja att köpa en tjänst på en konkurrensutsatt marknad. Vid en institutionsplacering är socialtjänsten kund medan de placerade barnen/ungdomarna kan ses som brukare. Om pris prioriteras före kvalitet eller om man inte har underlag för att bedöma vad som är god eller dålig vård är det inte de kontraktsslutande parterna (institutionen och socialtjänsten) som drabbas, utan de placerade barnen och deras familjer. Dessutom kan situationen kompliceras ytterligare om placeringen sker mot de berörda personernas vilja eller om barn/ungdomar och deras föräldrar inte har samma intresse eller bedömer situationen olika. ${ }^{3}$ Lagstiftningen talar om att socialtjänstens åtgärder skall utformas i samverkan med den enskilde, och att man skall lyssna till både de ungas och föräldrarnas synpunkter men här har forskning visat att det finns uppenbara brister i den praktiska

3 Placeringar med tvång, det vill säga enligt Lagen med särskilda bestämmelser om vård av unga, LVU (1990:2) utgör cirka en fjärdedel av samtliga placeringar. 
handläggningen (Sundell \& Egelund 2000, Socialstyrelsen 2003).

\section{Pengar och privata HVB-hem}

I princip innebär marknadifiering och kund-säljarförhållanden att relationen mellan den tjänst man får och det pris man betalar kommer i fokus. Av privatiseringsförespråkare brukar detta användas som ett argument för effektivare resursutnyttjande och lägre kostnader inom den offentliga sektorn. Kritikerna å sin sida resonerar omvänt och befarar att marknadslösningar ger privata aktörer möjlighet att pressa ut överpriser av exempelvis kommuner som ofta inte har något annat val än att betala.

Ekonomerna Lindqvist och Sandblom (2003) menar att det finns så många aktörer inom institutionsvården för barn och unga att ingen kan dominera marknaden. De höga informationskostnaderna och det faktum att köpare och brukare av tjänsterna inte är samma person innebär dock en tröghet när det gäller att uppnå marknadsjämvikt, vilket enligt författarnas bedömning kan göra det möjligt för företag att göra höga vinster. Den långsiktiga bedömningen är dock att marknaden har en tendens till nollvinst eftersom inträdeshindren är låga, vilket bör leda till att fler kan konkurrera om utrymmet på marknaden.

Som vi skall se längre fram $i$ texten är variationen stor $i$ de vårdavgifter hemmen tar ut av kommunerna. En tänkbar förklaring bakom skillnaderna är vilken slags marknad hemmen befinner sig på samt vilken position man har på den. I analysen skall undersökas hur företrädare för HVB- hemmen själva uppfattar marknaden och den egna positionen där samt hur dessa faktorer hänger samman med nivån på vårdavgiften.

Sammanfattningsvis: institutionerna befinner sig på en vårdmarknad med låga trösklar för nyetablering och där det saknas både inom- och utomprofessionella grindvakter. Den tjänst som köps/säljs är innehållsmässigt oklar och det saknas kunskap om vårdens kvalitet och/eller effekter. Detta innebär vida ramar för institutionerna vad gäller verksamhetens organisering och prissättning av tjänster. För kunden/brukaren uppstår svårigheter att veta hur olika vårdalternativ skall värderas både kvalitetsoch prismässigt.

\section{Metod}

I studien har föreståndare för privata HVBhem intervjuats om hur de beskriver sitt agerande på vårdmarknaden. Intervjupersonerna har också fått frågor om hur de ser på relationerna till socialtjänsten. Det viktigt att påpeka att det endast är den ena parten i denna relation som kommer till tals.

Man skall också komma ihåg att det är just föreståndarna vid HVB-hemmen som intervjuats. Deras roll är att företräda och ansvara för verksamheterna både inåt och utåt. De har tillfrågats om områden som kan uppfattas som känsliga, exempelvis pengar och pengars betydelse i deras arbete. Frågan om ersättningar har då och då ventilerats när det gäller institutionsvården (Socialstyrelsen 1990) men betraktats som laddad eller i det närmaste tabubelagd inom familjehemsvården (Sunesson 1990, 
Höjer 2001). Det finns en risk att svaren på känsliga frågor påverkas av att föreståndarna är just föreståndare och av att de är verksamma inom ett område där pengar är ett kontroversiellt ämne. Detta måste tas med i beräkningen när man bedömer deras svar.

Materialet består av strukturerade telefonintervjuer med företrädare för 97 HVB-hem. Intervjuerna har gjorts utifrån ett formulär med i huvudsak frågor med fasta svarsalternativ och tog vanligen 20-30 minuter.

Vid undersökningstillfället fanns 338 privata eller stiftelsedrivna HVB för barn och ungdomar förtecknade. ${ }^{4}$ Bland dessa gjordes ett slumpmässigt urval på 118 HVB-hem, vilket representerar en dryg tredjedel. Fem hem uteslöts för att de visade sig inte tillhöra populationen. Åtta var nedlagda eller hade slutat bedriva aktiv verksamhet. Den slutliga undersökningsgruppen kom att bestå av 105 hem. Vid åtta av dessa ville man inte bli intervjuad, vilket ger ett bortfall på sju procent.

Resultatet av telefonintervjuerna har när det gäller frågan om vilka faktorer som har samband med nivån på HVB-hemmens vårdavgifter bearbetats med hjälp av multipel linjär regressionsanalys. Metoden ger möjlighet att studera vilket samband en viss variabel har med utfallet (i det här fallet

4 Uppgifterna bygger dels på den förteckning över HVB-hem som ges ut av Katalogdata (2002) dels de uppgifter som samlats in av Riksrevisionsverket i samband med en undersökning av tillsynen av HVB-hem (RRV 2002:6). Det finns idag inget myndighetsregister över vilka HVB-hem som driver verksamhet i landet. vårdavgift) med hänsyn taget till de andra faktorer som ingår i modellen (se Bryman \& Cramer 2001, Edling \& Hedström 2003).

Studiens resultat får anses riksrepresentativt. Den slumpade undersökningsgruppen representerar cirka en tredjedel av alla HVB-hem i landet som riktar sig till barn och ungdomar.

\section{Resultat}

Inledningsvis skall hemmens ägandeformer och etableringsprocess belysas. Därefter behandlas hur man från HVB-företrädarnas sida ser på sin position på marknaden samt vilka strategier man har för sitt agerande. Avslutningsvis analyseras variationen $i$ hemmens vårdavgifter.

\section{Ägandeformer}

Inom kategorin enskilda HVB-hem finns olika ägandeformer vilket framgår av Tabell 1. De allra flesta verksamheter, närmare nio av tio, utgörs av aktiebolag, handelsbolag eller enskild firma. Det finns i undersökningsgruppen bara en mindre grupp hem man kan betecknas som ideellt drivna. Det rör sig om ekonomiska föreningar eller stiftelse-/föreningsdrivna hem, vilka sammanlagt utgör tio procent av de enskilda hemmen. Här finner man institutioner som drivs av exempelvis Frälsningsarmén eller Stadsmissionen. I mitten av 1990-talet utgjorde de ej vinstdrivande enskilda hemmen 11 procent (Sallnäs 2000), i stort samma andel som idag. 
Bland de undersökta hemmen är 36 procent del av ett större bolag, de tillhör vad man lite tillspetsat skulle kunna kalla "vårdkoncerner", om än små sådana. Det rör sig vanligtvis om bolag som driver HVB-hem på olika orter men i samma del av landet eller om verksamheter som parallellt med institutionsvård arbetar med konsultation, terapi eller olika slags vård/behandling $i$ mer eller mindre öppna former. Det största bolaget driver tre större HVB och har runt hundra anställda. Detta är dock ett undantag, vanligare är att bolagen driver några mindre verksamheter och har mellan tjugo och trettio anställda sammanlagt. Det framkommer således i materialet inga tendenser till organisering kring stora dominerande eller riksomfattande aktörer. Snarare är huvudbilden ett tämligen fragmentariserat fält som domineras av små fristående verksamheter (Jfr Ware et al. 2001), men där man kan se inslag av små »koncerner". Här är det viktigt att påpeka att två stora vårdkoncerner inte är med i studien. De är bägge aktiebolag, men i kommunal ägo. Den ena koncernen driver sex institutioner plus annan verksamhet och har 135 anställda.

\section{Tabell I.}

HVB-hemmens ägandeform, $(n=97)$. Andel (\%).

\begin{tabular}{lc}
\hline Ägandeform & Procent \\
\hline Aktiebolag & 84 \\
Handelsbolag & 5 \\
\hline Enskild firma & 1 \\
Ekonomisk förening & 2 \\
\hline Stiftelse/ideell förening & 8 \\
\hline Totalt & $\mathbf{1 0 0}$
\end{tabular}

Den andra presenterar sig som Sveriges största vårdorganisation inom HVB-vården (för unga och vuxna). Man bedriver 15 institutioner för ungdomar och 11 för barn/ barnfamiljer (uppgifterna kommer från respektive organisations hemsida). De bägge koncernerna är inte riksomfattande men kan ses som mycket dominerande inom sin respektive region.

En särskild kategori utgörs av den grupp verksamheter man kan kalla familjehemslika HVB. De har ofta tidigare varit familjehem och är idag små HVB-verksamheter. Här har något som tidigare var ett uppdrag vid sidan av det vanliga arbetet blivit en heltidssysselsättning och försörjningskälla i småföretagets form. De familjehemslika HVB-hemmen omfattar 42 procent i materialet. I dessa verksamheter drivs ett företag med den egna familjen och det egna familjelivet som bas. Vid drygt hälften bor någon i personalen på institutionen (se också Sallnäs 2002, 2003). Här går familje- och institutionssfären bokstavligen ihop och skall förenas med företagandets villkor.

\section{Etableringsprocess}

Materialet visar att det varit ett stort inflöde av nya verksamheter på fältet. I runda tal två tredjedelar av hemmen i studien har startat som HVB från år 1990 och framåt.

Hemmen har olika etableringsprocesser bakom sig. Endast en mindre grupp (9 procent) har omvandlats från att vara offentligt drivna till att bli privata verksamheter. Vid dessa hem uppger drygt hälften av föreståndarna att skälet till att man över- 
gick till privat drift var att verksamheten annars skulle lagts ner. Den absoluta majoriteten privata HVB har emellertid från början startats i den form de har nu. Privatisering inom detta område tycks alltså inte i första hand ha varit politiskt planerad på det sättet att offentliga verksamheter omvandlas till privata. Det är istället frågan om nyetablering och om det Dellgran och Höjer (2003) kallar "spontan privatisering", det vill säga att anställda som tidigare haft offentliga arbetsgivare (exempelvis socialtjänsten) startar eget eller tar anställning $i$ privata företag inom samma fält (se också Österberg 2003). Samtidigt har HVB-hem givetvis lagts ner, men i vilken omfattning det skett säger studiens material inte något om.

Intervjupersoner som startat privat $\mathrm{HVB}$ motiverar detta delvis utifrån ett entreprenörsperspektiv. Man har velat göra något nytt eller annorlunda än vad offentliga huvudmän gör. Cirka en tredjedel uppger att man sett behov av viss slags vård som inte funnits tillgänglig och cirka en fjärdedel att man varit missnöjd med hur den offentliga vården bedrivits. En mindre grupp (cirka 15 procent) betonar vikten av företagandet i sig och uppger att man startat för att man velat bli sin egen och arbeta självständigt (se Butler 1992 om varför socialarbetare vill driva eget företag).

Enligt Dellgran och Höjer (2003) kan privatisering ses som en strategi för att öka det professionella inflytandet över arbetet och ge det ökad status och legitimitet. Det kan också vara ett sätt för dem som är missnöjda med sitt arbete i offentlig sektor att få en ändrad situation. Bland föreståndarna som intervjuats vid de privata HVB- hemmen kan hälften tänka sig att ha motsvarande arbete i offentlig sektor, medan resten utesluter denna möjlighet. Cirka 90 procent menar att det är skillnad mellan att driva HVB offentligt och privat (en del har gjort det och kan jämföra respektive driftsform, andra inte). Man betonar sådant som att engagemanget är större när man är sin egen, att man som privat föreståndare inte har någon ekonomisk buffert (till skillnad från om man arbetar offentligt) och att beslutsvägarna är kortare och effektivare.

Sammantaget kan man konstatera att de intervjuades motivering till att ha startat HVB varierar från att betona brister och luckor i den offentliga vården till att se själva driftsformen - att ha eget företag - som det viktigaste. På fältet finns med andra ord klart entreprenörsinriktade aktörer, som kanske lika väl kunnat driva verksamhet inom något annat område. För andra handlar incitamenten till att starta HVB mer om själva vård-/behandlingsuppgiften. Här är det svårt att veta om svaren är påverkade av intervjupersonernas position som företrädare för verksamheten och av deras uppfattning om vad man kan och får säga $\mathrm{i}$ frågor som rör drivkrafter och motiv.

\section{Position på marknaden och strategier för agerande}

Kommunernakan i princip välja vilket HVBhem man vill även om det i lagstiftningen finns en norm om att placeringar skall göras i barnets närhet när så är möjligt. Det råder alltså i formell mening en konkurrenssituation mellan de olika HVB-hemmen. Denna 
inskränks dock om hemmen riktar sig till olika ålders- och målgrupper eller har olika inriktningar på sin verksamhet. Eventuell konkurrens får därför främst anses gälla gentemot andra hem inom samma nisch. Marknaden tycks emellertid till väsentliga delar vara befolkad av aktörer som själva uppfattar att deras verksamhet styrs av andra krafter än konkurrens. När företrädare för HVB-hemmen tillfrågas om sin position på marknaden framgår att nästan 60 procent i ganska låg grad eller inte alls ser sig som verksamma på en konkurrensutsatt marknad.

Det finns skillnader mellan olika kategorier av hem. Det är signifikant fler bland de familjehemslika hemmen än bland övriga som inte ser sig (i ganska låg grad/inte alls) som verksamma på en konkurrensutsatt marknad (76 respektive 45 procent, $\mathrm{p}<0,01)$.

Även om man vid en majoritet av hemmen inte uppfattar sig som konkurrerande aktörer är en ansenlig del marknadsaktörer i den meningen att man vidtar olika aktivite-

\section{Tabell 2.}

I vilken utsträckning ser företrädare för HVB-hemmen sig som verksamma på en konkurrensutsatt marknad? ( $n=97)$. Andel (\%).

\begin{tabular}{lc}
\hline & Procent \\
\hline I mycket hög grad & 8 \\
I ganska hög grad & 34 \\
I ganska låg grad & 36 \\
Inte alls & 22 \\
\hline Total & $\mathbf{1 0 0}$
\end{tabular}

ter för att förmå kunden (socialtjänsten) att anlita just det egna HVB-hemmet. Cirka hälften av hemmen (51 procent) bedriver någon av följande marknadsföringsaktiviteter: tidningsannonser, utskick till socialkontor, telefonsamtal/besök hos socialtjänsten för att erbjuda tjänster, deltagande i mässor och konferenser, evenemang och seminarier. En mindre grupp (18 procent) kan betecknas som "offensiva marknadsförare»; de anger fyra eller fem aktiviteter. En dryg fjärdedel uppger två eller fler aktiviteter. Antalet marknadsföringsaktiviteter hemmen ägnar sig åt har ett signifikant samband med i vilken grad man uppfattar sig som verksam på en konkurrensutsatt marknad $(\mathrm{r}=0,34, \mathrm{p}<0,01)$. Föga förvånande har hem som i större grad uppfattar sig som konkurrensutsatta fler marknadsföringsaktiviteter än övriga. De familjehemslika hemmen står för minst marknadsföring. Endast vid cirka vart tredje sådant HVB (30 procent) bedriver man någon marknadsföring och inget tillhör gruppen offensiva marknadsförare. Bland hem som tillhör koncerner är det en signifikant större andel som är offensiva marknadsförare.

Vid närmare nio av tio hem (87 procent) uppfattar föreståndarna att det är kommunernas tidigare kännedom om HVBhemmet som är det viktigaste när det gäller hur socialtjänsten får kunskap om verksamheten. Detta pekar mot att parallellt med hemmens allmänt riktade marknadsföring, finns ett system som innebär att köp/säljrelationerna mellan HVB-hemmen och socialtjänsten upprättas via enskilda personer och till stor del bygger på tidigare kontakter. HVB-hem och socialtjänst ingår i ett gemensamt nätverk av personer som känner 
varandra och som tidigare sålt/köpt vård av varandra. Vid vissa HVB-hem tycks finnas något som närmast kan ses som en allians med socialtjänsten, vilket enligt intervjupersonerna innebär att kommunernas placeringar påverkas av när ett visst HVB har en plats ledig - en informell matchning av socialtjänstens arbete och HVB-hemmens beläggningssituation. Detta kan vara en av förklaringarna till att så pass många inte uppfattar sig som konkurrensutsatta aktörer. Personliga relationer mellan säljare och köpare är särskilt framträdande bland de familjehemslika hemmen. Ett liknande mönster av etablerade kontakter mellan tjänstemän i kommunerna och privata aktörer inom social- och hälsovård har rapporterats från Finland (Österberg 2003).

Mindre än hälften av hemmen (42 procent) har så kallade ramavtal med kommunerna. Ett sådant avtal innebär att HVBhemmet och kommunen i förväg har kommit överens om vilka villkor som skall gälla om en placering kommer till stånd, exempelvis beträffande avgiftsnivå, kontakter och typ av vårdinsats. Vissa hem har ramavtal med endast en eller ett fåtal kommuner medan andra kan ha det med upp till 50 kommuner. Färre familjehemslika HVB än övriga har denna typ av överenskommelse (24 procent respektive 55, $\mathrm{p}<0,01)$. Om placeringar i familjehemslika HVB i hög grad bygger på socialtjänstemännens tidigare kännedom om verksamheten tycks detta inte i första hand ta sig formella uttryck i form av ramavtal.

Vid en placering skall socialtjänsten och HVB-hemmet komma överens om olika aspekter av vården, men också om pris och om vilka åtaganden respektive part har. Intervjupersonerna har fått frågan om vilken part de uppfattar är starkast vid en placering. Bland de 78 intervjupersoner som svarar på frågan menar sex av tio att HVB-hemmet är den starkare parten i detta sammanhang och 22 procent menar att det skett en förändring över tid som inneburit att HVB-hemmen blivit allt starkare.

De allra flesta intervjupersoner (78 procent) menar emellertid att man kan karakterisera förhållandet till socialtjänsten som ett samarbete mellan kollegor, inte ett kund/säljarförhållande. Närmare en fjärdedel anser dock att det skett en förändring som inneburit att relationerna med socialtjänsten alltmer kommit att ta sig uttryck som ett kund/säljarförhållande. Trots detta uppger cirka hälften av intervjupersonerna att socialtjänsten sällan eller aldrig ställer krav på eller ifrågasätter innehållet $\mathrm{i}$ vården och sex av tio att man sällan eller aldrig frågar efter utvärderingar eller kvalitetsuppföljningar vid en placering

Intervjuerna visar att den privata HVBvården (och kommunerna) endast till liten del arbetar enligt närhetsprincipen (unga skall i möjligaste mån placeras i närheten av familj och nätverk). Eventuell konkurrens för hemmens del råder alltså inte enbart mot andra institutioner i regionen utan $\mathrm{i}$ ett större geografiskt område. Bland HVBhemmen $\mathrm{i}$ undersökningen har cirka 55 procent hälften eller mer av sina placeringar från kommuner utanför det egna länet. Endast var femte hem (21 procent) har bara lokala placeringar. Att vård vid privata hem innebär avsteg från närhetsprincipen uppmärksammades av Socialstyrelsen i början av 1990-talet och framkommer också i en riksrepresentativ studie av 1991 års ton- 
årsplaceringar (Socialstyrelsen 1990, 1991, Vinnerljung et al. 2001, se också Riksrevisionsverket 2002). I den sistnämnda visas att avvikelse från närhetsprincipen var utmärkande just för de enskilda HVBhemmen. I brittisk forskning rapporteras samma mönster av en stor andel icke-lokala placeringar vid de privata hemmen (Gibbs \& Sinclair 1998). Där har man funnit att detta har samband med sämre kontakt med barnens ursprungsmiljö och dålig lokal förankring av institutionen. Om dessa konsekvenser av att inte tillämpa närhetsprincipen också gäller för svenska institutioner säger föreliggande studies material inget om. Däremot skall visas längre fram $\mathrm{i}$ texten att andelen icke-lokala placeringar är en signifikant faktor i relation till nivån på hemmens vårdavgifter.

\section{Ekonomi, avgiftsnivåer och marknad}

De privata hemmen är helt beroende av vårdavgifter för att täcka sina utgifter (och för eventuell vinst). Att bedriva privat HVB innebär att både vårda/behandla och att driva ett företag utifrån ekonomiska prioriteringar. Av undersökningen framgår att de företagsmässiga och ekonomiska aspekterna av HVB-verksamheten är något som vållar problem för en ansenlig grupp bland intervjupersonerna. En tredjedel (33 procent) av de intervjuade tycker det är svårt att fastställa vårdavgiften och ungefär lika många att ekonomin är ett besvärligt område.

När det gäller den lite mer kontroversiella frågan om det finns en motsättning mellan de ekonomiska sidorna i en privat verksamhet och arbetet med barnen menar cirka en fjärdedel av HVB-föreståndarna (24 procent) att de ser ett sådant dilemma. Många betonar det ständigt närvarande kravet på beläggning för att få intäkter via vårdavgifterna. Ur ekonomisk synpunkt är det sårbart om en plats är tom under någon längre tid. I små verksamheter representerar varje enskilt barn dessutom en väsentlig del av ekonomin.

Själva den omständigheten att de flesta privata HVB-hemmen är vinstsyftande företag och, som många av intervjupersonerna påpekar, inte har någon ekonomisk buffert att ta till i trängda lägen är uppenbarligen problematisk. Även om det som nämnts har varit låga trösklar för att starta ett HVB-hem, är det när det väl är igång en relativt sett "tung" och stationär verksamhet. De personer som har startat hemmen har satsat pengar och ibland är, som nämnts, också deras egen bostadssituation direkt kopplad till verksamheten (se Sallnäs 2003).

Vilket pris sätter då de privata hemmen på sina tjänster och hur hänger prissättningen ihop med marknadsfaktorer respektive olika egenskaper hos hemmen? Undersökningen visar att det är en påfallande stor variation i vårdavgifter, vilket framgår av tabell 3. Ett vårddygn kan kosta mellan $1100 \mathrm{kr}$ och $6120 \mathrm{kr}(\mathrm{m}=2355 \mathrm{kr}, \mathrm{sd}=837$ kr). På månadsbasis innebär det en kostnad som kan variera mellan drygt $30000 \mathrm{kr}$ och $180000 \mathrm{kr}$. De flesta privata hemmen (90 procent) har genomsnittliga vårdtider på mer än ett år för barnen. Det är alltså årskostnader på mellan $400000 \mathrm{kr}$ och drygt 2 miljoner kronor som är aktuella. Två hem utgör extrema högkostnadsställen. Om 
man räknar bort dessa ligger de återstående på nivåer upp till $4400 \mathrm{kr} /$ dygn. Eftersom det bara finns tio hem som kan karakteriseras som icke-vinstdrivande i materialet är det svårt att jämföra dessa med de vinstdrivande hemmen. Det allmänna mönstret är att de ideella/stiftelsedrivna hemmen är fördelade i mitten av kostnadsintervallet, men inget finns vid polerna.

Man skall komma ihåg att vårdavgiften kan avse vård/behandling av olika slag. I urvalet finns t.ex. verksamheter som enbart arbetar med utslussning, vilket kan innebära att ungdomarna bor i egna lägenheter men har stöd av personal. Detta är naturligtvis en mindre personalkrävande (och därmed billigare) verksamhet än mer regelrätt institutionsvård. I det nedre intervallet finns två sådana verksamheter.

Det går givetvis inte att säga att en viss vårdavgift är för hög eller för låg, eller att det skulle finnas en nivå som är "rätt». Däremot framstår det som rimligt att pris och kvalitet hänger samman och som nämnts pekar tidigare studier mot ett samband mellan en kvalitetsaspekt som personaltäthet och avgiftsnivå (Lindqvist \& Sandblom 2003).

Vilka faktorer har då samband med

Tabell 3.

Vardavgifter vid privata HVB-hem, (n=94). Andel (\%)

\begin{tabular}{lc}
\hline Avgiftsnivå & Procent \\
\hline $1100-2000 \mathrm{kr} /$ dygn & 42 \\
$2100-3000 \mathrm{kr} /$ dygn & 46 \\
$3100-6120 \mathrm{kr} /$ dygn & 12 \\
\hline Total & $\mathbf{1 0 0}$
\end{tabular}

avgiftsnivån vid de enskilda HVB-hemmen? Med hjälp av nedanstående modell har denna fråga analyserats. I modellen ingår dels grupper av variabler som har att göra med hemmen som sådana (målgrupp, struktur och kvalitet) dels faktorer som skall fånga hur man vid hemmen uppfattar sin marknads- och konkurrenssituation.

- Målgruppen vid hemmet

De hem vars avgifter jämförs i analysen bör agera på samma marknad i den meningen att de vänder sig till ungefär samma grupp av barn och unga. I modellen ingår därför om institutionen tar emot den grupp av ungdomar som ofta uppfattas som tyngst, nämligen unga med asocialt beteende (våld, kriminalitet och missbruk). Asocialt beteende hänger intimt samman med att vara tonåring, varför variabeln "målgruppens ålder" uteslutits. Däremot ingår om institutionen är "enkönad", det vill säga riktar sig till endast pojkar respektive flickor. Knapp och Smith (1985) fann i en studie av offentliga hem att en majoritet av flickor bland de placerade hängde samman med lägre kostnader. Slutligen ingår en faktor som säger hur stor andel av de placerade barnen vid institutionen som kommer utanför det egna länet, alltså ett mått på i vilken utsträckning HVB-hemmen (och placerande socialtjänst) frångår närhetsprincipen.

Variabler: institutionen tar emot ungdomar med våldsamt beteende, kriminalitet eller missbruk (ja/nej), »enkönad" institution (ja/nej), andel distansplaceringar. 
- Verksamhetens struktur

Det kan ha betydelse för vårdavgiften vilken slags HVB-verksamhet det rör sig om. Det är därför viktigt att konstanthålla några strukturaspekter på hemmen. Här ingår om institutionen är del av ett större bolag (en koncern). Vidare ingår $i$ analysen om institutionen har egen skolverksamhet för de placerade ungdomarna. Knapp och Smith (a.a.) har med denna fråga i sin undersökning av offentliga hem, men fann att den inte hade någon betydelse för kostnaden. Slutligen ingår i denna kategori av variabler om institutionen tidigare varit familjehem. De tidigare redovisade resultaten tyder på att verksamheter som tidigare varit familjehem men omkonstituerat sig till HVB, befinner sig i en annan slags marknadssituation än övriga hem.

Variabler: institutionen del av ett större bolag (ja/nej), har egen skola (ja/nej), har tidigare varit familjehem (ja/nej).

\section{- Verksamhetens kvalitet $\mathrm{i}$ vid mening}

Det är rimligt att tänka sig att det antal vuxna personer som kan ägna sig åt de placerade ungdomarna säger något om kvaliteten på den vård som bedrivs. En annan variabel som kan ses som uttryck för kvalitet är personalens utbildningsnivå. Om det är behandling $\mathrm{i}$ någon slags professionell mening som HVBhemmen erbjuder, bör det finnas personal med särskild utbildning som kan ge behandlingen.

Variabler: personaltäthet (antal personal/antal platser), utbildningsnivå (andel bland personalen som har hög- skoleutbildning inom det sociala/psykologiska/pedagogiska området)

- Hemmets marknads-/konkurrenssituation

Både i vilken grad man ser sig som aktör på en konkurrensutsatt marknad och hur man beskriver efterfrågan på hemmets tjänster speglar respondenternas uppfattning om verksamheten och dess relationer till marknaden. I analysen ingår också ett mått på hur offensiva marknadsaktörer institutionerna är genom en variabel som anger hur många marknadsföringsaktiviteter man bedriver vid respektive HVB-hem.

Variabler: i vilken grad man ser sig som aktör på en konkurrensutsatt marknad, hur man bedömer efterfrågan, antal marknadsföringsaktiviteter.

Tillsamman "förklarar» de i modellen ingående variablerna 60 procent av variationen i vårdavgift mellan de olika hemmen. ${ }^{5}$ Modellen visar att den utan tvekan starkaste påverkansfaktorn på vårdavgiften är personaltäthet (antal personal/antal plat-

5 I modellen har alla institutionerna i undersökningen tagits med. Om man tar bort de två verksamheterna med extremt höga avgifter sjunker den förklarade variansen något, men det blir ingen skillnad i vilka variabler som blir signifikanta. Extremvärdena bekräftar alltså snarast de samband modellen visar. Modellen blir inte heller märkbart annorlunda om man utesluter de ideella/stiftelsedrivna verksamheterna. Den förklarade variansen höjs något men det blir ingen skillnad i signifikanta variabler. Det spelar inte heller någon roll om man utesluter de riktigt små hemmen ur analysen. 
ser vid institutionen). Med andra ord: ju större tillgång till personal för de placerade barnen desto dyrare vård. Personaltäthet står ensam för en stor del av den förklarade variansen $(0,49)$ och skulle kunna vara en faktor som även fångar upp andra egenskaper hos hemmen. Så är dock inte fallet, personaltäthet är inte starkt korrelerad med övriga bakgrundsvariabler.

Andelen högskoleutbildad personal har inte någon signifikant inverkan på vårdavgiften. En möjlig förklaring är att det är antalet personer som är anställda som kostar pengar medan skillnader i lön som har att göra med utbildningsnivå är relativt små. Det är uppenbarligen inte heller så att en personalgrupp med högre formell utbildningsnivå ger legitimitet för högre priser.

Analysen visar också att det har betydelse ur avgiftssynpunkt om HVB-hemmet är del av ett större bolag eller inte. Cirka 35 procent av hemmen tillhör ett bolag, som driver ytterligare HVB-hem. Här finns som nämnts tidigare mindre bolag med ett fåtal HVB-hem men också i verklig mening vårdkoncerner. De hem som tillhör ett huvud-

\section{Tabell 4.}

Faktorer relaterade till vårdavgifter vid privata HVB $(n=93)$. Linjär regressionsanalys. ${ }^{*}$

\begin{tabular}{|c|c|c|}
\hline & $\begin{array}{l}\text { Standardiserad regres- } \\
\text { sionskofficient }\end{array}$ & Signifikansnivå \\
\hline $\begin{array}{l}\text { Tar emot ungdomar med våldsamt beteende, } \\
\text { kriminalitet eller missbruk }\end{array}$ & 0,033 & 0,654 \\
\hline »Enkönad« institution & 0,114 & 0,123 \\
\hline Andel distansplaceringar & 0,226 & 0,005 \\
\hline Institutionen del i ett större bolag & 0,167 & 0,046 \\
\hline Har egen skola & 0,041 & 0,581 \\
\hline Institutionen har tidigare varit familjehem & 0,047 & 0,572 \\
\hline Personaltäthet & 0,693 & 0,000 \\
\hline Utbildningsnivå6 & 0,028 & 0,720 \\
\hline $\begin{array}{l}\text { I vilken utsträckning man ser sig som aktör på } \\
\text { konkurrensutsatt marknad }\end{array}$ & $-0,026$ & 0,738 \\
\hline Bedömning av efterfrågan & 0,100 & 0,190 \\
\hline Antal marknadsföringsaktivitet & 0,052 & 0,512 \\
\hline \multicolumn{3}{|l|}{${ }^{*} \mathrm{R}^{2}=0,60$} \\
\hline $\begin{array}{l}6 \text { Variabeln anger hur stor andel av personalen vid } \\
\text { kologiska/pedagogiska området på högskoleniva } \\
\text { 50-74 procent, 75-100 procent av personalgrup }\end{array}$ & $\begin{array}{l}\text { institutionen som har utbild } \\
\text { Den kan anta värdena: } 0-2 \\
\text { en. }\end{array}$ & $\begin{array}{l}\text { inom det sociala/p } \\
\text { ocent, } 25-49 \text { proce }\end{array}$ \\
\hline
\end{tabular}


bolag har högre vårdavgifter när övriga faktorer är konstanthållna. Det kan ha att göra med större overheadkostnader (exempelvis ledning och organisering), men också med vårdkoncernernas roll på marknaden.

Variabler som beskriver marknadssituation har över huvud taget ingen signifikant betydelse för vårdavgiften. Här ingår både hur företrädare för hemmen uppfattar sin situation som marknadsaktör (konkurrensutsättning, efterfrågan) och i vilken utsträckning man bedriver marknadsföring.

Det har däremot betydelse hur stor andel av barnen vid institutionen som är placerade långt bort från sin hemkommun. De hem som agerar på en större geografisk marknad är dyrare. Ett skäl skulle kunna vara att upprätthållande av kontakten med hemmiljön är fördyrande. Sambandet kan också vara ett uttryck för att socialtjänsten inte kunnat lösa problemen i lokalmiljön (inom länet) och mer eller mindre tvingats att acceptera högre vårdavgifter vid HVB-hem som ligger långt bort. Sådana förhållanden har rapporterats från Norge (Benedictow 1996). En annan tolkning är att socialtjänsten aktivt väljer ett visst hem för att man vill ha just det, trots avstånd och höga vårdavgifter. Ett motiv kan vara att vården är specialiserad eller att man vill motverka att ungdomar rymmer hem (se Vinnerljung et al. 2001). Det senare är enligt flera intervjupersoner ett viktigt skäl till att unga placeras med långt avstånd mellan hem och vårdmiljö.

Om man endast inkluderar hem som riktar sig till tonåringar i analysen kvarstår de signifikanta sambanden med de olika bakgrundsvariablerna men därtill kommer att specialisering mot flickor (däremot inte att man endast tar emot pojkar) hänger samman med högre vårdavgift. I motsats till resultaten i Knapp och Smith (1985) framstår alltså specicialisering mot tonårsflickor som något som motiverar högre priser på HVB-hemmens tjänster.

Det återstår en inte obetydlig variation $\mathrm{i}$ hemmens vårdavgifter som inte kan relateras till de faktorer som ingår i modellen. Högst troligt finns det betydelsefulla faktorer som inte är med i undersökningen. Det kan gälla sådant som har att göra med "insidan" på verksamheten, exempelvis i vilken utsträckning man arbetar med familjearbete, hur mycket internutbildning man står för, om och hur mycket handledning man har, vilka arbetsmetoder man använder, vilken vinst man tar ut i verksamheten osv. Det kan också vara så att vårdavgifter sätts utifrån helt andra premisser. Det är höga informationskostnader för den socialtjänsteman eller politiker som skall välja vårdalternativ. Det är svårt att få kunskap om vilka institutioner som är "bra» respektive "dåliga» (hur man än väljer att betrakta vad som är bra eller dåligt) vilket gör det svårt att väga pris mot kvalitet. Det kan med andra ord finnas skillnader i vårdavgift som är slumpmässiga, som inte har att göra med någon särskild identifierbar faktor eller omständighet. Med tanke på fältets karaktär är det inte osannolikt att vårdavgifter $\mathrm{i}$ vissa fall kan sättas helt skönsmässigt eller efter, för en utomstående, outgrundliga principer.

\section{Sammanfattning och diskussion}

En viktig utgångspunkt för artikeln har varit att det, trots regler om tillståndsgiv- 
ning och tillsyn, ställs låga krav för att få starta privata institutioner. Detta har lett till en omfattande etablering av aktörer i vinstsyftande verksamheter som säljer vård till mycket varierande priser. De privata HVB-hemsföreträdarna uppfattar emellertid endast till viss del att de är aktörer på en konkurrensutsatt marknad. Cirka hälften av hemmen bedriver marknadsföring för att övertyga kommunerna om att köpa deras tjänster, men man betonar personliga relationer och tidigare kännedom som det viktiga i köp/sälj-kontakterna med socialtjänsten.

Marknadifieringen tycks har stärkt HVB-hemmens position. En majoritet av de intervjuade HVB-föreståndarna uppfattar HVB-hemmet som den starkare parten vid kontakterna med socialtjänsten i samband med en placering. Ett uppenbart och grundläggande problem på den marknad som upprättats är de höga transaktionskostnaderna och den informationsbrist som råder ur kommunernas (och brukarnas) synvinkel. Socialtjänsten saknar grundläggande information om den tjänst de betalar mycket varierande priser för och de som är direkt berörda - placerade barn/ungdomar och deras familjer - är sällan med i själva köp/säljprocessen.

Det är viktigt att beakta fältets speciella karaktär. Den tjänst som köps och säljs är resultatet av en åtgärd som berör endast en mycket liten grupp i befolkningen, en grupp som inte lätt gör sin röst hörd och som inte finns bland samhället starka. Klass, kön och etnicitet är markörer för den sociala utsatthet som utmärker familjer där barnen placeras i dygnsvård (Lundström \& Sallnäs 2003). Ur de berördas familjernas synpunkt kan socialtjänstens beslut om vård och val av vårdform vara direkt livsavgörande. De berörda barnen och föräldrarna befinner sig i en svår situation där krav på att agera rationellt som brukare kan vara orimliga. Givetvis skall inget barn placeras i vård eller i en viss vårdform för att ett HVB-hem behöver belägga sina platser. Här finns ett problem om man från HVB-hemmen agerar så starkt för att klara sin beläggning att det faktiskt påverkar hur socialtjänsten beslutar om placeringar.

För att socialtjänsten skall kunna få kunskap om i vilken utsträckning HVBhemmen uppnår olika former av behandlingsmål krävs kriterier för att bedöma vårdens kvalitet och utfall och systematiska utvärderingar och uppföljningar. Detta görs dock sällan och undersökningen visar att få kommuner frågar efter sådan kunskap då en placering skall genomföras. Det finns heller inget fungerande system för kommuner att utbyta information med varandra om HVBhemmen och deras vård, något alla kommuner förmodligen skulle vinna på.

I artikeln framkommer att det är anmärkningsvärda skillnader i de avgifter de privata hemmen sätter på sina tjänster. Det går naturligtvis inte att bortse från att avgifterna kan hänga samman med vårdens kvalitet i djupare mening (mätt på annat sätt än som personaltäthet och personalens utbildningsnivå) och dess utfall. Man skulle kunna säga att det egentligen är orimligt att diskutera avgiftsnivåer isolerat från en tydlig diskussion om vad man får för pengarna (se Knapp \& Smith 1985). Det kan ses som att jämföra priset på oxfilé och falukorv utan att ta hänsyn till att det rör sig om helt olika slags matvaror. Jag menar att 
man trots allt måste ställa frågan om hur man skall förstå den mycket stora variation i vårdavgifter som finns inom det här området, även om man inte har tillgång till utfallsdata eller kvalificerade uppgifter om vårdens kvalitet. En fråga man kan ställa sig är om det finns samband mellan vinster och löneuttag i verksamheterna och höga vårdavgifter. Dessvärre saknas data för en sådan analys.

Analysen visar att "marknadsvariablerna巛 inte har någon signifikant betydelse för hur hemmen sätter sina vårdavgifter när man tagit hänsyn till faktorer som verksamhetens målgrupp, struktur och kvalitet. Däremot är personaltäthet en signifikant faktor för nivån på vårdavgiften, när man kontrollerat för andra variablers inverkan. Om kommunerna betalar mer får de också en personalintensivare vård, oavsett hur hemmens position på marknaden ser ut. Mer personal kan hänga ihop med bättre vård men det är långt ifrån säkert. Andreassens (2003) kunskapsöversikt pekar ut helt andra faktorer som väsentliga för hur institutionsvård för asociala ungdomar lyckas i den meningen att beteendeproblem hos ungdomar minskar. Det viktiga är inte främst hur många anställda man har per ungdom, utan snarare hur man arbetar, hur man involverar familjen, att personalen har en gemensam uppfattning om vården osv. Samtidigt måste det rimligen finnas en lägsta nivå på personaltäthet för att det skall vara möjligt att ge god vård.

Att personalens utbildningsnivå inte har betydelse för vårdavgiften kan sannolikt förstås utifrån fältets generellt låga professionaliserings- och utbildningsnivå. Det är inom detta område inte formell kompetens eller professionella attribut som krävs för att ge en verksamhet legitimitet och det är inte heller sådana faktorer som slår igenom i prissättningen.

En "strukturvariabel" som att verksamheten är del av ett större bolag hänger samma med högre vårdavgifter. Här kan man fråga sig om kommunerna betalar för en administrativ överbyggnad eller om större bolag $\mathrm{i}$ genomsnitt har bättre vård än fristående verksamheter. Eller är det så att man riktar sig till olika grupper, men att detta inte fångats tillräckligt väl i den analysmodell som använts?

Andelen distansplaceringar vid hemmen är en ytterligare faktor som hänger samman med högre avgift vid hemmen. En stor del av de unga som finns vid HVB-hemmen i studien är placerade utanför sitt hemlän och detta blir alltså dyrare för kommunerna.

\section{Avslutning}

Som framgått av artikeln är den vårdmarknad som upprättats inom institutionsvården behäftad med uppenbara svårigheter och begränsningar. Marknadifiering av välfärdsstatens olika delar har motiverats med ökad valfrihet, konkurrens och kostnadseffektivitet. Inom socialtjänstens institutionsvård för barn och ungdomar är svårigheterna med att uppnå dessa mål uppenbara inte minst eftersom den tjänst det rör sig om är så oklart formulerad och beskriven? Vad säljer man och vad köper man? Och vad får man för pengarna? 


\section{Litteratur}

Andreassen, T. (2003) Institutionsbehandling av ung domar: vad säger forskningen? Stockholm: Gothia, Centrum för utvärdering av socialt arbete (CUS) och Statens institutionsstyrelse (SiS).

Benedictow, M. (1996) Ungdomi saertiltak: en undersokelse av akershusungdom som med hjemmel $i$ barnevernloven og med eget samtykke er plassert $i$ saertiltak for ungdom med alvorlige atferdsvansker. Oslo: Institutt for medisinske atferdsfag.

Blomqvist, P. \& Rothstein, B. (2000) Välfärdsstatens ansikte: demokrati och marknadsreformer inom den offentliga sektorn. Stockholm: Agora.

Bryman, A. \& Cramer, D. (2001) Quantitative data analysis with SPSS release for Windows. East Sussex: Routledge.

Butler, A. (1992) "The Attractions of private practiceu. Journal of social work, vol. $28 \mathrm{nr}$ 1. s. 47-61.

Dellgran, P. \& Höjer, S. (2003) »En delad och ambivalent profession: socionomers attityder till privatisering av socialt arbeter. Socionomens Forskningssupplement, nr 15 s. 17-36.

Edling, C. \& Hedström, P. (2003) Kvantitativa metoder: grundläggande analysmetoder för samhällsoch beteendevetare. Lund: Studentlitteratur.

Egelund, T. \& Heastbeck, A-D. (2003) Anbringelse af børn og unge uden for hjemmet: en forskningsoversigt. Köpenhamn: Socialforskningsinstituttet 03:04.

Gibbs, I. \& Sinclair, I. (1998) „Private and local authority children's homes: a comparision". Journal of Adolescence, nr 21, s. 517-527.

Hannan, M. och Freeman, J. (1989) Organizational Ecology. Cambridge: Harvard University Press.

Hugemark, A. (2004) Med rätt att bestämma själv? - "exit, voice och personlig assistans». I Kerstin Gynnerstedt (red.) Personlig assistans och medborgarskap. Lund: Studentlitteratur.

Höjer, I. (2001) Fosterfamiljensinre liv. Göteborg: Institutionen för socialt arbete, Göteborgs universitet.

Katalogdata (2002) Förteckning över hem för vård eller boende och familjevårdsenheter. Sigtuna.

Kilsved, H. och Hartelius, B. (1993) Privata institutioner för vård eller boende ökar sin andel av länets vårdmarknad. Stockholm: Länstyrelsen i Stockholms län.
Knapp, M. \& Smith, J. (1985) „The cost of residential child care: explaining variations in the public sector". Policy and Politics, vol. $13 \mathrm{nr} 2$, s. 127-154.

Knapp M., Hardy B. \& Forder J. (2001) „Commissioning for quality: ten years of social care markets in England". Journal of Social Policy, vol. 30 nr 2, s. 283-306.

Kotler, P. \& Armstrong, G. (2004) Principles of marketing (tenth edition). Upper Saddle River, New Jersey: Pearson Prentice Hall.

Lindqvist, E. \& Sandblom, J. (2003) Privat drift $i$ den svenska institutionsvården. Stockholm: Handelshögskolan, opublicerad uppsats.

Lundström, T. \& Sallnäs, M. (2003) »Klass, kön och etnicitet i den sociala barnavården". Socialvetenskaplig tidskrift, vol.10 nr 2-3, s. 193-213.

Montin, S. (1996) Kommunala förnyelseproblem: en statsvetenskaplig betraktelse. Bilaga I till slutbetänkande av kommunala förnyelsekommittén. SOU 1996:169.

Riksrevisionsverket (2002) RRV 2002:6 Tillsyn av behandlingshem för barn och ungdomar. Stockholm.

Sallnäs, M. (2000) Barnavårdens institutioner: framväxt, ideologi och struktur. Stockholm: Institutionen för socialt arbete, Stockholms universitet.

Sallnäs, M. (2002) „Mellan institutionsliv och familjeliv - om små privata institutioner för barn och ungdomaru. I Ingrid Söderlind (red.) Uppväxt, familjeformer och barns bästa. Stockholm: Institutet för framtidsstudier.

Sallnäs, M. (2003) „Som en familj? Om små privata institutioner för barn och ungdomar". Socionomens forskningssupplement, nr 15, s. 2-16.

Socialstyrelsen (1990) Vård utom hemmet, SoSrapport 1990:4. Stockholm.

Socialstyrelsen (1991) Privat och offentligt i vården. SoS-rapport 1991:27. Stockholm.

Socialstyrelsen (1994) Barn- och ungdomsinstitutioner: Hur påverkas vården av kommunernas ekonomiska situation? Socialstyrelsen följer upp och utvärderar 1994:10. Stockholm.

Socialstyrelsen (2002) Vårdens värde: vad fär vi för pengarna i vaird och omsorg? Stockholm. 
Socialstyrelsen (2003) Socialtjänsten i Sverige: en översikt 2003. Stockholm.

SOU 2001:79, Välfärdsbokslut för 1990-talet, slutbetänkande. Kommittén Välfärdsbokslut. Stockholm: Fritzes offentliga publikationer.

Storø, J. (1998) "Privatisering i barnevernet». Norges Barnevern, nr 3.

Sundell, K. \& Egelund, T. (2000) Barnavairdsutredningar: en kunskapsöversikt. Stockholm: Gothia/CUS

Sundin, E. (1997) „Den offentliga sektorns omvandling och kvinnors och mäns företagande inom typiskt kvinnliga sektorer». I SOU 1997:83 Om makt och kön i spåren av offentliga organisationers omvandling. Stockholm: Fritzes offentliga publikationer.

Sunesson, S. (1990) „Familjevården, en del av individ- och familjeomsorgen i socialtjänsten«. I Sju perspektiv på barns och ungdomars levnadsför- hållanden. SoS-rapport 1990:5. Stockholm: Socialstyrelsen.

Trydegård, G-B. (2001) „Välfärdstjänster till salu privatisering och alternativa driftformer under 1990-talet». I SOU 2001:52 Välfärdstjänster $i$ omvandling, Kommittén Välfärdsbokslut.

Ware P., Matosevic T., Forder J., Hardy B., Kendall J. \& Knapp M. (2001) "Movement and change: independent sector domiciliary care providers between 1995 and 1999". Health and Social Care in the Community, vol. 9 nr 6, s. 334-340.

Vinnerljung B., Sallnäs M. \& Kyhle Westermark P. (2001) Sammanbrott vid tonairsplaceringar: om ungdomar i fosterhem och på institution. Stockholm: CUS/Socialstyrelsen.

Österberg, J. (2003) »Att dansa på lina: egen företagsamhet inom social- och hälsovård». Nordiskt Socialt Arbeid, vol $23 \mathrm{nr}$ 2, s. 81-88.

\section{Summary}

\section{A care market with problems On private entrepreneurs in residential care for children and youth}

Residential care for children and adolescents are to a growing extent operated by private corporations, the majority of them being "for-profit" organizations. This article discusses the care market that has emerged in this field during the last few decades. Heads of privately run homes have been interviewed about process of establishing homes and about their position and way of acting on the market. An important point of departure is that there are few obstacles and barriers to starting private homes. This has led to a highly differentiated residential landscape, characterized by low levels of control by the state. The field is characterized by weak gate-keeping, both externally and by professionals. The "marketization" of the field seems to have strengthened the position of the homes in relation to child welfare. However, quite a few of the respondents do not regard themselves as entrepreneurs on a market. The concept of market is in several ways difficult to use in this particular part of child welfare. The buyer/seller relation is complicated and it is unclear what different forms of care actually consist of. This makes it difficult to relate quality of care to the noteworthy differences in what price social welfare pays for placing children in the homes. The analysis shows that having a high density of personnel in the home, being part of a bigger company and having many children placed a long way from home are associated with more expensive care. 